\title{
From Multi-Sited Ethnography to Food Heritage: What Theoretical and Methodological Challenges for Anthropology?
}

\author{
De la etnografía multisituada al patrimonio alimentario. \\ ¿Qué desafíos teóricos y metodológicos para la antropología?
}

\author{
Charles-Édouard de Suremain \\ UMR 208 PALOC (IRD-MNHN)-CIESAS, France-Mexico \\ ID ORCID: https://orcid.org/0000-0001-5547-5781 \\ E-mail: suremain@ird.fr
}

Recepción: 5.02.2019

Aprobación: 20.12.2019

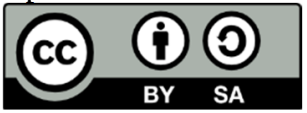

\begin{abstract}
Through three Latin American examples, the paradigmatic notion of "multi-sited ethnography" is put to the test in relation to food heritage. After recalling its cultural and historical antecedents in Europe and Latin America, a first set of tensions between "institutionalized heritage" and "ordinary heritage" are analyzed. The phenomena of contestation (Bolivia) that food heritage produces among the most modest populations shows that the wide range of its meanings and uses depend on the context and local issues. Consequently, the potentially contentious relationships between various actors within heritage, gastronomic tourism, and development are highlighted. For this purpose, the example of "female traditional cooks" and "gastronomic routes" in Mexico is used as a starting point. Through these examples, the advantages and limitations of the multi-sited approach and its implications for ethnographic work on food heritage are discussed. Specifically, emphasis is put on the conditions of its implementation by revisiting how it differs from the comparative approach, transnationalization and "glocal" analysis. Finally, some theoretical and methodological avenues for further exploration in the critical anthropology of food heritagization are suggested.
\end{abstract}

Keywords: Latin America, food heritage, tourism, development, multi-sited ethnography.

Resumen: A partir de tres ejemplos latinoamericanos, propongo poner a prueba la noción paradigmática de "multisitio" a través del patrimonio alimentario. Tras recordar los antecedentes culturales e históricos de esta última en Europa y América Latina, analizaré una primera serie de tensiones entre el "patrimonio establecido" y el "patrimonio ordinario". El fenómeno de la contestación 
(Bolivia) que el patrimonio alimentario genera entre las poblaciones más modestas muestra la gran diversidad de sus significados y usos según los contextos y las problemáticas locales. A continuación, destacaré el carácter potencialmente conflictivo de las relaciones entre los distintos actores del patrimonio, el turismo gastronómico y el desarrollo. Comenzaré con el ejemplo de las "cocineras tradicionales" y las "rutas gastronómicas" en México. Sobre estas bases, se discutirán las contribuciones y limitaciones del enfoque multisituado y sus implicaciones para el trabajo etnográfico sobre el patrimonio alimentario. Volveré, en particular, sobre las condiciones de su aplicación, volviendo a las diferencias que muestra con la perspectiva comparativa, el análisis transnacional y el análisis "glocal". Finalmente, se propondrán algunas pistas teóricas y metodológicas de reflexión para la antropología crítica de la patrimonialización de la alimentación.

Palabras clave: América Latina, patrimonio alimentario, turismo, desarrollo, enfoque multisituado.

\section{INTRODUCTION}

Various concepts currently in vogue in anthropology, originating from latetwentieth century postmodern criticism, advocate in favor of "emerging anthropologies" (Sarkis Fernández \& Sarkis Fernández, 2007). Their core ideas include encouraging a less hegemonic way of doing fieldwork, interrogating writing as a form of domination, promoting the decentralization of anthropology, and supporting dialogic anthropology. ${ }^{1}$ The realization that fieldwork sites are not isolated, but that they are part of the "global", progressively led to the emergence of "multi-sited" ethnography, founded on the "(...) metaphor of 'following' or 'trailing' to evoke the logic of moving space in ethnography, stemming from the confines of fieldwork" (Marcus, 2002). Other newly emerging notions included "transnationalization" (Csordas, 2009), "glocalization" (Robertson, 1995), or "ethnoscapes" (Appadurai, 1996), which interrogate the processes by which collective identities are reconfigured by groups scattered across the world. With these new paradigms, anthropologists seem "off-centered" in theoretical terms, and they also decenter their gaze in a given spatiality. This, in turn, leads them to exhibit more "positive superficiality" (thinness according to Geertz [1973]) in their understanding of an observed phenomenon and its analysis. Their place in the field is, by extension, relative and circumstantial, oscillating between reflexive and "thick" participation (to use another Marcus's term, 1998) and "circumstantial integration" (Rabinow, 1999).

Here I examine three sites, with the intention of revisiting the theoretical and methodological challenges posed by the paradigmatic notion of "multi-sited

\footnotetext{
${ }^{1}$ See, among others, Geertz (1973), Rabinow (1977), Clifford \& Marcus (1986), Beck, Giddens \& Lash (1994), Marcus (1995), Escobar (1995), Appadurai (1995[1991], 1996, 2001), and Marcus \& Fisher (1999[1986]).
} 
ethnography" in the study of food heritage. The sites that will be discussed in this text are not part of an ethnographic investigation that was originally conceived as multi-sited. In other words, each of the sites described here is originally part of an independent study, the research at each site having taken place at different times, even though all the research was focused on food issues. It was only after conducting the fieldwork and from the methodological and theoretical lessons that emerged that questions about the links between the multi-site approach and food heritage became apparent. The choice of the three sites analyzed in the text therefore aims to contribute to the reflection on food heritage based on the methodological questioning that has gradually evolved.

More precisely, from the research experiences revisited here, following the same analytical grid, I test the concept of multi-sited ethnography in relation to food heritage, and consider the contributions and limitations of comparavitism, the transnational, and the translocal. First, I explore the hypothesis advanced by Ghasarian (2004: 22) on the study of localized meanings and re-significations of cultural practices and phenomena; currently, given the intensifying processes of globalization, it seems unavoidable to envisage food heritage - which is both a concept and a category of action with a universal scope — as a subject provoking numerous forms of appropriation, interpretation, transformation, re-signification, modification, and/or rejection at various levels (local, national, regional). ${ }^{2}$ After offering some contextual information about the conditions in which food heritage appeared, I explore the relationships between institutionalized heritage $e^{3}$ and the ways in which it is culturally and politically challenged starting from a specific "food heritage configuration"4 (Bolivia). This is followed by an analysis of the convoluted ambiguity that characterizes the relationships between heritage, development, and gastronomic tourism, using two different examples from Mexico. Finally, these considerations enable a discussion on the contributions and limitations of multi-sited ethnography and help advance several theoretical and methodological proposals for the anthropology of food heritage.

\footnotetext{
${ }^{2}$ These reflections and propositions have been developed in the framework of the FoodHerit project (Food heritage and gastro-politics: a critical and comparative approach, CULT-2013, http://foodherit.hypotheses.org/), funded by ANR (France).

${ }^{3}$ In the anthropological sense (Abélès, 2008), all practices and ceremonies are "institutions" as far as local actors are concerned (in the same way as kinship, for example). Here the expression "institutionalized heritage" is used in the sociological sense of the term: this refers to an institution as it is recognised in formal and normative terms, such as UNESCO.

4 That is to say, situations where the issue of heritage-its recognition, safeguarding, and promotion--are expressed using other words or terms than those used by UNESCO, words which examine a great diversity of actors with divergent interests. Here I owe my inspiration to Olivier de Sardan's notion of "developmentalist configuration" (1997), which I developed in my book Fabricacteurs de patrimoine (2015).
} 


\section{FOOD HERITAGE: A DIVERSE RESEARCH SUBJECT WITH UNIVERSAL SCOPE}

It is appropriate to summarize some key points before proposing a working definition of food heritage. Since the 1980s, a sort of "heritage buzz" (Juhé-Beaulaton et al., 2013) seems to have conquered the world as a result of UNESCO's intervention (Bendix, 2012; Berliner \& Bortolotto, 2013). ${ }^{5}$ This phenomenon dates back to 1982, when the Mexico City Declaration on Cultural Policies ${ }^{6}$ recog- $^{-}$ nized the importance of "(...) the work of anonymous artists, expressions of the people's spirituality, and the body of values which give meaning to life". The text extends the field of heritage, previously limited to "high" arts and staged performances: it now includes "delicate" productions (such as music, dance, and mythology) and "popular actors", often native people, who become "carriers" of culture.

UNESCO's 1989 Recommendation on the Safeguarding of Traditional Culture and Folklore was a response to the risks of homogenization of cultural practices and values in the face of globalization, industrialization, and urbanization across the world. The guiding idea was that, thanks to this universal recommendation, non-Western cultures, hitherto excluded from the real (tourism) and symbolic (identity) benefits propagated by cultural enhancement, could now enjoy a certain universal recognition, at least in a symbolic way. Several texts, such as the Universal Declaration on Cultural Diversity (2001/2002), culminated in the 2003 Convention for the Safeguarding of Intangible Cultural Heritage (ICH). ${ }^{7}$ This one now integrated social practices, expertise, and "common knowledge" and thus opened the way for the recognition of food as heritage.

It is important to note that the context was marked by acrimonious debates between the United States and the rest of the world regarding "cultural diversity" and the status of cultural assets. The underlying idea of the Convention, in other words, was to curb the almost inexorable trend towards the commodification of cultural productions, transforming them into just another kind of consumer good. The Convention was to some extent part of the recurring debate in anthropology on cultural appropriation. Several countries highlighted the urgency of finding alternatives in response to the spread of free trade of cultural productions. According to Csergo (2016b: 191), they argued for "(...) the development, outside

\footnotetext{
${ }^{5}$ The works of the historians Heinich (2009) and Csergo (2016a and $b$ ) go back much further into the origins of heritage, particularly in the case of France, and link them closely to its political history.

${ }^{6}$ Article 23: http://portal.unesco.org/culture/fr/files/12762/11295422481mexico_fr.pdf/mexico_fr.pdf.

${ }^{7}$ For a better overview of the whole process, see Bortolotto (2011). For the definition of ICH, see http://www.unesco.org/culture/ich/en/convention.
} 
the WTO [World Trade Organization], vulnerable to pressure from the United States (...), of an international tool for cultural diversity, controlled by UNESCO [precisely in order to control commercial excesses resulting from cultural appropriation]". The Convention on the Protection and Promotion of the Diversity of Cultural Expressions was adopted in 2005. Yet, however much these expressions are embedded in heritage, they are nevertheless subject to the rules of the various states, only partially escaping the rules of international trade, and, consequently, also subject to the Convention, which is supposed to act at the level controlling international trade rules.

Since then, food heritage has occupied a significant place in both civil society and the spheres of politics and the media (Langlois, 1999; Tornatore, 2004; Bertacchini et al., 2016). In recent years, new nomination files to food heritage have multiplied: "Today, [these nominations] represent a total of 10\% (29 out of 291) of the elements inscribed. (...) their share has gone from 3.5\% in 2009 to $18 \%$ in 2015 , in which year they represented $22 \%$ of inscriptions on the Representative List" (Csergo, 2016b: 198-199).

In 2005, Mexico was the first country to present a nomination file on food heritage to the "representative list of the intangible cultural heritage of humanity" (Moncusi \& Santamarina, 2008). The application was refused due to alleged links between the experts and the corn lobbies, and their disinterest in local communities. The second nomination file presented received just as much criticism (Ayora Díaz \& Vargas Cetina, 2010; Ayora Díaz, 2012), but was inscribed in 2010, under the evocative title of "Traditional Mexican cuisine-ancestral, ongoing community culture". The region of Michoacán was supposed to represent the archetypal form of the country's cuisine. At the same time, the "gastronomic meal of the French" was also selected, but for different reasons. Finally, in 2013, the "Mediterranean diet", a nomination file submitted by several countries of the Mediterranean basin and more generally of the region (Cyprus, Croatia, Spain, Greece, Italy, Morocco, Portugal), was presented and approved in its turn, but again for different reasons.

Food occupies a strikingly different place in each of these three nomination files (Csergo, 2011), to the extent that it seems complicated to offer a balanced definition of food heritage. I propose using the following relatively broad and functional definition proposed by Matta (2016: 338-339):

[It encompasses] all sets of food knowledge and skills considered by groups as shared legacies or common goods (Bessière \& Tibère 2010). Food heritage includes agricultural products, ingredients, dishes and cooking artifacts. It also comprises the symbolic dimension of food 
(table manners, rituals), techniques, recipes, eating practices and food-related behaviors and beliefs; and it extends to processes of selection, decontextualization, adaptation and reinterpretation. It is, therefore, a historical, cultural and social construction that combines 'conservation and innovation, stability and dynamism, reproduction and creation' (Bessière, 1998: 27). As such, one can only understand food heritage by the role it has been granted and the interests it serves. (Espeitx 2004)

Based on these contextual factors, I will now consider some of the tensions inherent in the use of food heritage, and then give a concrete example of how multi-sited ethnography may be applied.

\section{FIRST TENSION: INSTITUTIONALIZED HERITAGE VS. ORDINARY HERITAGE}

UNESCO's ambition is clearly universalist, whether in relation to food heritage or other forms of heritage, tangible and intangible. The establishment of institutions across the world-and the proliferation of the heavy load of texts, inscription and evaluation procedures, and regulations that support them-contributes to the production and implementation of a uniform conceptual category that transcends borders and cultures (Arizpe \& Amescua, 2013; Bertacchini et al., 2016). However, local variations, performances, words, and expressions of heritage, and even the value accorded to heritage in different places, remain extremely diverse, creative, and unique (Bondaz et al., 2014; Guillaud et al., 2016). That is the case even without considering the implicit, even invisible, heritage configurations related to what Isnart (2012) calls "ordinary heritagization"a sort of social practice that escapes the field of formal institutions and organizations. These configurations can lead to "politically incorrect" types of heritages, at odds with the usual application form for intangible heritage supported by UNESCO, as I show in the Bolivian example below.

\section{The apthapi as a "politically incorrect" collective meal?}

An archetypal example of food practices that display heritage values, without actually referring to the concept of heritage explicitly, is apthapi, a collective meal widespread across the Bolivian countryside and towns alike (Suremain, forthcoming). ${ }^{8}$ Apthapi is an ancient institution of peasant origins, probably from the colonial period, which developed considerably during the mining boom (Nash, 1979). In the past, it marked the beginning of the harvest period and one

\footnotetext{
${ }^{8}$ In the Aymara language, the verb apthapiñar also means "to gather", "to reap", or "to collect the profits of one's labour".
} 
of its functions was to form an alliance between the available workers-or the community of lineages - who would be undertaking the harvests. The principle behind it is more or less identical everywhere: apthapi brings together a varying number of guests to share food and drink, which participants have prepared and then brought to share with the group. Apthapi refers to both the meal itself and the action of "pooling" something, in this case food.

The apthapi I attended took place in town, specifically within the Sociology Faculty at the University of Cochabamba (the country's second-largest city). The students planned to organize a demonstration against tuition fee rises. The meal gave them an opportunity to exchange points of view and agree on their course of action. During this festive meal, the guests followed the peasant Andean model of commensality, sitting on the floor; likewise, the manners at the table were rather informal: everyone served themselves directly from the dishes, taking as much as they wanted, without any order of precedence according to status or gender. The guests formed a large circle as the food passed quickly from hand to hand. Food was also distributed to those who had remained outside the circle due to lack of space. Furthermore, the guests' clothing was not festive. They were dressed as they do every day, without any particular adornment. Everything was as if the guests were "at home" and felt at ease with each other: "it's ours!" "“ies lo nuestro!"), they said, referring both to the apthapi as a specific and shared moment, as well as to the meal or the prepared foods. Finally, the atmosphere was also very relaxed: the conversations were natural, laughter broke out, and chicha (a fermented local drink of varying strength made from corn, peanuts, cassava, or rice) circulated among the group. However, guests were not restricted to drinking chicha; they also drank beer, singani (a grape juice distillation of varying strength), or wine, with or without soda. Inevitably, the guests began to dance to the sound of a somewhat improvised band or sometimes a sound system. Generally, it is rare that an apthapi ends because the food has run out. It is customary for each guest to return home with some provisions.

Through these activities, the guests affirmed their feeling of belonging to a social group and, by extension, their compliance with various social, political, and cultural expectations. The upcoming demonstration occupied everyone's thoughts and frequently arose in conversations, however fragmented they were. In town, I was able to observe apthapi without participating, bringing together groups such as taxi drivers, mothers in a particular neighborhood, trade unionists, and even politicians. In all settings, the little community of actors that shares their pooled food literally forms a "body": what matters here is less what is actually in 
the food-the "concrete productions" of food (Csergo, 2011: 17) — than the direction of conversations, the sense of mutual understanding, and the decision or action to come.

Another factor confirms the evident political dimension of apthapi: the tradition of using great colored flags to announce that the event is being held. In $\mathrm{La}$ Paz, in particular, the colors evoke not only the Bolivian flag but also the wiphala, also known as the "Aymara flag", after the region's dominant indigenous ethnolinguistic group. Its use is not limited to indigenous populations and its origin remains rather vague. Some claim it has pre-Columbian origins, while others argue it was invented relatively recently in the great miners' marches organized by the Revolutionary Liberation Movement Tupaq Katari (MRTKL) in the 60s and 70s. ${ }^{9}$ Whatever its history, the wiphala is regularly displayed during demonstrations by students or miners and it represents much more than a classic statement of ethnic sentiment. It expresses the struggle of ordinary citizens against multiple inequalities and reveals the hope for a more just society. The wiphala unites the vast majority of the population, without reference to social or cultural origins. Beyond the modalities of how it is used, which can vary between social categories, the apthapi makes explicit certain social, cultural, political, economic, territorial, and/or identity tensions. These are very contemporary and localized and draw all their meaning from the wider context of Bolivian society.

It is highly unlikely that apthapi be recognized as "heritage" by UNESCO, not because of the great diversity of its expression. On the contrary, this characteristic would be a strong point to a UNESCO nomination. The real issue here is that the apthapi shows a cultural practice largely associated with the rural and/or urban "poor". Because of its evocation, even indirectly, of poverty, the apthapi points to a series of tensions, even limits, to institutional heritage recognition. The first tension concerns the contradiction between "institutionalized heritage" and "ordinary heritage": to what extent can an institution contribute to the enhancement of a cultural practice that is linked to poverty and that could be confused with its expression? The second refers to the huge gap between "culturally correct heritage" (Nielsen, 2013) and what I call "politically incorrect heritage" (Suremain, forthcoming). To what extent can an institution contribute to the enhancement of a cultural practice that, from its own point of view, may be "in-

\footnotetext{
${ }^{9}$ According to the Instituto Nacional de Arqueología Boliviana (INAR), the wiphala consists of six colours (green, blue, purple, red, orange, yellow), arranged in 44 squares, 7 columns and 7 lines. Each colour has a meaning, particularly purple which refers to "the Andean ideology", social organisations, administration, etc.
} 
correct" insofar as this practice does not represent culture (here food) in a spectacular or exotic way, but, on the contrary, in a very ordinary way? There is no doubt that the apthapi is "incorrect" in that it makes visible various social, political, and cultural expectations from those left behind by society. Of course, the apthapi is not "incorrect", far from it, for those who participate in it. But in the event that the apthapi are recognized as a heritage, it would constitute an important precedent. It would mean that the cultural practices of urban and poor populations, usually unrecognized in Bolivian public space, could be recognized in the same way as those populations that usually are perceived to embody "authentic" cultural difference.

\section{The apthapi as an ordinary form of political protest?}

Attempts have been made to appropriate apthapi for political ends, both by the Bolivian government for demagogic reasons and by the tourist sector for economic ones. One might suspect that, because of these appropriations, the popular urban strata would be reluctant to embrace the apthapi. However, the exact opposite happened, because this appropriation helped to ensure the apthapi's success in the media and, as a result, to make it known to people who did not necessarily use it before. In fact, in the promotional websites of many travel agencies, the apthapi is presented as a "legacy of the Andean tradition" and is renamed variously as the "collective Andean meal", "comida indigena comunitaria", or "native picnic". In response to the circumstances, the apthapi served to tourists are sold as organic "health-food" creations and are loosely inspired by Andean peasant dishes. Can apthapi constitute a regular source of income for Andean communities situated along eco-tourism routes (Barrera \& Bringas, 2009)? For this to be the case, the peasants would have to have control over setting up and managing these routes-which is far from being the case today. A possible institutional recognition of apthapi by UNESCO is therefore unlikely, given the asymmetry of power relations between the actors concerned. If the communities and local populations were able to take control of their destiny, this form of heritage would embody a new "alternative resource" (Bondaz, Isnart \& Leblon, 2012), a sort of mastery of institutionalized heritage. Until this unlikely outcome is achieved, the apthapi plays an important role in Bolivian political life at several levels and there is a good chance that it will continue to transmit and amplify the voice of ordinary citizens. 


\section{SECOND TENSION: FOOD HERITAGE VS. TOURISM AND DEVELOPMENT}

In Mexico, and in other Latin American countries such as Peru, Brazil, and Ecuador, the development of food resources as heritage is emerging as a major social issue. ${ }^{10}$ This process mobilizes the economic and tourist sectors as well as various groups of actors with diverging interests (decision-makers, local authorities, industrialists, entrepreneurs, professional bodies, communities, small producers, and restaurateurs, among others). This can be seen in the Ley de Fomento a la Gastronomía Mexicana, which was recently approved by the President (2015). Once validated, this will equip several sectors of the economy with significant financial and legal means for promoting "Mexican gastronomy". Very loosely inspired by the dossier approved by UNESCO, this law has been criticized by anthropologists and national historians for taking sides with the agro-industrial sector and, particularly, with the tourism sector, which is becoming an almost all-consuming priority for development. ${ }^{11}$ Academics argue that the law is instrumentalist and mercantile and that it supports an elitist vision of gastronomy, to the detriment of the huge diversity of local cuisines and the multiple representations underlying them. Numerous authors highlight the effects of exploiting the recognition of heritage by UNESCO. ${ }^{12}$ This can be seen not only in the significant number of celebrations, festivals, markets, and gastronomic competitions, but also in the private museums (chocolate, tequila, wine, coffee, insects...) which extol Mexican products by assigning them hitherto lost nutritional values or symbolic connotations. On these occasions, the promotion of heritage primarily concerns super foods. In Mexico, the main examples are amaranth (leaves and seeds), cocoa, and chia (seeds) ${ }^{13}$. Originally part of the daily diet of the poorest people, these super foods are now invested with every possible virtue ("sustainable", "healthy", "fair"). They thus find global success and end up adorning the tables of the rich.

\footnotetext{
${ }^{10} C f$. Zabludovski (1996), Arizpe (2006), Arizpe \& Amescua (2013), Brulotte \& Di Giovine (2014), Brulotte \& Starkman (2016), Castellanos \& Bergstresser (2016).

11 The Claustro de Sor Juana, the only university in the country to offer a Licenciatura de gastronomia, formed a task force, which I was invited to join in 2016, to alert the Senate to the potential commercial effects of applying the law and the economic and symbolic inequalities which are likely to result from it in various regions and industries. $C f$. the critical interview given by C. Barros, a member of the task force, in a major daily newspaper: http://www.otroangulo.info/otromundo-es-posible/cristina-barros-valero-en-defensa-de-la-comida-mexicana/

${ }^{12} C f$. for example Álvarez (2004), Tellström Gustafsson \& Mossberg (2006), Areski et al. (2009), Bessière (2013), Johnson \& Barry (1995), Csergo (2016a).

${ }^{13}$ In Peru, it is maca (root) and lucuma (fruit), in the Bolivian and Ecuadorian Andes, quinoa (pseudocereal), and in Brazil, açai (berry) (cf. Matta, 2013; Katz \& Lazos, 2017).
} 


\section{The case of "female traditional cooks" (Mexico)}

"Female traditional cooks" (locally called cocineras tradicionales and, notably, never "chefs") illustrate the ambiguous effects of classifying Mexican gastronomy as heritage. In what appears to be a rather conservative, and ultimately phallocentric perspective, female cooks are presented as the "substance" of this cuisine, and the basis of its recognition by UNESCO, thus enjoying a relatively prestigious status. The female cooks usually come from the relatively poor states of Oaxaca, Michoacán, or Yucatán, often from humble villages, and are thought to embody "community solidarity", "native wisdom", "peasant know-how", and "maternal and familial kindness" - in short, the authentic values of an ancestral gastronomy embodied by the products of the milpa. ${ }^{14}$ According to the representatives of the Conservatorio de la Cultura Gastronómica Mexicana who presented the nomination file to UNESCO's "representative list" in 2010, the female cooks come from local groups of "indigenous women" that existed well before heritagization. ${ }^{15}$ They have been sustained by their community, the gastronomic sector, the Conservatorio, and then by UNESCO. These women, who are transmitters and protectors of heritage, nevertheless know how to adapt to modern times by taking training courses in management, hygiene, microfinance, or communication... and all while wearing their traditional dress. According to the official account of the Conservatorio (see footnote 15), today these women travel around the country and sometimes abroad, giving demonstrations, participating in competitions and festivals, and developing their own restaurants to welcome tourists. Some become caterers and find international fame. ${ }^{16}$ Despite this, success for some does not necessarily lead to success for others, and particularly not for the female cooks' communities of origin. The benefits of all kinds, which are not hard to evaluate,

\footnotetext{
${ }^{14}$ From the word meaning both subsistence cropping as a specific space -which includes a large group of plants such as corn, beans, squash, and chilli- and the associated agricultural technique. Milpa forms both a unit of familial production potentially self-sufficient, and a strong symbolic space (Ellison, 2004). On Mexican heritage, see Arizpe Schlosser (2006). On the inscription of Mexican gastronomy by UNESCO, see the very critical analysis of Iturriaga (2010).

15 The Conservatorio de la gastronomía mexicana is a semi-public, semi-private structure, both a state foundation and a private business (http://www.ccgm.mx/ccgm/) $C f$. "El expediente de la cocina Mexicana ante la Unesco", a communication from López Morales \& Rubín de la Borbolla (of the Conservatorio...), International Symposium "Patrimonios alimentarios: consensos y tensiones", 30/11-02/12/2015, IIA-UnAM (Mexique).

${ }^{16} C f$. the career paths of Juana Bravo: http://www.eluniversal.com.mx/articulo/estados/2017/01/2/cocineras-mujeres-indigenas-rescatan-la-comida-tradicional-mexicana and Benedicta Alejo Vargas, who cooked for Pope Benedict XVI : http://www.animalgourmet.com/2016/12/17/nueve-cocineras-tradicionales-conservan-secretos-la-cocina-mexicana/.
} 
accrue primarily to the individual, and do not bring with them the expected local development so announced by the Conservatorio in its website.

One of these female traditional cooks, whom I met in Mexico City at a "networking" fair about organic farming and insects and wished to remain anonymous, confided in me that she had been forced to leave her village near Oaxaca to go to Mexico City, because of the extent to which her media success had attracted "conflict and jealousy" from some of her family and neighbors. However, in front of the camera of a major television channel (TV Azteca), she hid this information, instead speaking only about her vegetarian and vegan culinary creations, presented as "derived from tradition". In particular, the woman served vegetlayudas and veggietlayudas; tlayudas are tortillas made with corn from the Oaxaca region and measuring up to $40 \mathrm{~cm}$ in diameter, which may be prepared in many ways. The female cook was adept at wordplay, introducing ethical, ecological, and nutritional vegetarianism under the pretext of regional cooking. Whatever the case, this example of individual success for a "female traditional cook"that is ultimately relative, in any case-has had mixed results, to say the least. Paradoxically, although this woman has experienced a certain degree of success through promoting Mexican traditional gastronomy, the price she paid was a distancing, and even a split, from her community.

\section{The case of "gastronomic routes" (Mexico)}

Another example of the ambiguity of the heritagization of Mexican cuisine is found in the so-called "gastronomic routes". Although normative definitions are given by researchers (Barrera \& Bringas, 2004), regional and national public institutions, and travel agencies, in practice it is difficult to know exactly what is covered by these gastronomic routes, which in recent years have proliferated in almost all regions of Mexico. This can be analyzed on several levels. There are routes by food type (wine, mole ${ }^{17}$ chocolate, tequila, or mezcal), by particular "cultural traditions" (Maya, desert, colonial from the central valleys, or urban centers), or through links with tourism and gastronomy (chocolate and the pyramids, the plants of desert pilgrims, ${ }^{18}$ the mezcal of the haciendas, or the mole of

\footnotetext{
${ }^{17}$ This is an archetypal element of national cuisine. Although multiple recipes exist, it is generally a sauce made of chile, sesame, peanuts, chocolate (or cocoa), and tortilla crumbs.

${ }^{18}$ This route, indirectly linked to gastronomy, showcases desert food and the supply of endemic plants. It is one of the rare routes which was designed through a participative process by anthropologists (Alvarado Solís and González Costilla) and local people. $C f$. http://www.visitasanluispotosi.com/Principal/Descargables/RSaberes.pdf.
} 
the convents). At another level of analysis, routes may be identified according to promoters' subsidies: culture or tourist offices, various states, professional associations, groups of travel agencies, groups of researchers, or private initiatives. ${ }^{19}$ It seems that the process by which tourists and entrepreneurs within the touristic sector go through to participate in such routes is an important element in defining them. Most of the routes are sold as "packages", although a lot of them are promoted through tour books or websites. The large majority of tours are just tasting tours; very few involve participation in the agricultural or daily life of local populations, as is often the case in the eco-tourism sector.

These various routes are the setting for a range of events such as festivals, competitions, or food markets, all of which may be theatrical, professional, or every day to differing degrees. Generally, they mix commercial activities such as the sale of produce sale, artisanal trades from the region and beyond, and trade of supposedly "natural" medicines. These events include the Fiesta de los olivos $y$ de la alegría (an amaranth-based candy) and the Feria del mole, to mention just a couple of the most prestigious. Both of these take place around Mexico City and are situated on the city's gastronomic route, which is called El sabor de hoy ("the flavors of today"). These two events appear to be a sort of spectacular theatricalization of food heritage, mobilizing a wide variety of actors, decision-making authorities, and funding sources. Among the actors involved in organizing them, some come from the civil society, others from the private sector, and a few from the Mexican government. Ultimately, these events have extremely varied impacts in media terms, but they also bring economic benefits and symbolic validation for local populations, particularly small producers of the products that are apparently being celebrated.

I will briefly consider the example of the alegrias and the olive festival. When I was at the 2016 festival, an independent small producer, whose grandparents had exhibited the candy at the festival before her, explained to me that more and more stalls were occupied by small trading businesses or wholesalers. The festival's great media and tourist success had led the town council to raise the fees it charged to stallholders, forcing small producers to choose stalls that were less and less well-placed each year; this had thus contributed to weakening their businesses. That same year, another small producer decided to stop paying the fee, which had become too expensive, and instead walked around selling

19 Many routes do not have their own internet sites. One website that presents them is: http://rutasgastronomicas.sectur.gob.mx/descargas.jsp. 
candy from a bucket, thus risking a fine. In 2017, the year after, another small producer told me that, in the face of "unfair competition" on prices from traders, he had chosen to set himself apart by selling less amaranth and more chía. In his mind, this was not a corruption of the festival's original spirit, but rather his way of navigating the growth of the super foods market. The small producer was very well informed about the sales prices of chía in organic grocers in Mexico City and he offered an attractive price that allowed him to recoup some of what he had lost with the fall in his sales on the alegrías.

In settings that are supposed to embody "the character of the Mexican people", the traders' and wholesalers' stalls offer numerous foodstuffs, artisanal goods, and medical products. Virgins of Guadalupe and little sugar cars are mixed with everyday objects (frying pans, cutlery, and citrus presses) and "miracle products" made of "natural produce" with multiple therapeutic virtues. The billboards show a mixture of images of amaranth, Maya pyramids, Aztec warriors, organs of the body, and contemporary peasants with Amerindian features. However, the most astonishing stall I have seen was a reconstruction of a supposedly North American indigenous hut, featuring its proprietor toasting amaranth seeds on a large terracotta tray placed directly on the embers. Dressed in an "Amerindian" style, the owner took his role very seriously and did not hesitate to reply to technical questions from onlookers. To the most interested among them, he rushed to offer vacuum-packed packets of candy or amaranth, decorated with patterns recalling the vision of Mexicanness displayed on the billboards. These bizarre stagings have an ironic dimension, but they also insidiously reveal the profound asymmetry of power relations between exhibitors. The extravagant representations of amaranth reveal the extent of the economic and symbolic dispossession from which small producers suffer. These small producers are a long way from mastering the codes of marketing and communications and are less visible in the space due to the bad location of their stalls. Their experience is thus far removed from the exotic, artificial, and totally anachronistic fantasy narrated by their competitors to promote their own sales.

\section{Public actors, private actors, and promoters of heritage}

It seems clear the actors of civil society who participate directly or indirectly in these various kinds of heritage initiatives - communities, neighborhoods, or individual adults and children-do not move in economic, social, political, and cul- 
tural spheres that are totally isolated, in opposition, or are mutually exclusive. In fact, we might accept that the initiatives coexist and interact within the same space.

Nevertheless, the power relations in that space are profoundly unequal. As is true in multiple places (Matta, 2010; Timothy, 2016), ordinary, everyday cuisine is subject to considerable appropriation by the gastronomic, tourist, and industrial sectors, which benefit from the support of public authorities-notably through fiscal incentives. Through cross-sector funding, the federal and state authorities in Mexico also encourage local initiatives, but this is always on the condition that they are profitable, as was recently the case with the regional heritagization of Yucatán's cuisine (Ayora Díaz, forthcoming). In the same way, some regions have witnessed the promotion of "female traditional cooks" and "gastronomic routes", the new actors I have considered above. These two examples strongly illustrate the various contradictions that are liable to result from the cynical promotion of food heritage, tourism, and development in a general context suffused with neoliberalism.

\section{THEORETICAL AND METHODOLOGICAL TESTING}

In light of the three examples presented above, what lessons can be drawn by applying the paradigmatic concept of multi-sited ethnography? And what more general theoretical and methodological propositions can be envisaged for the anthropology of food heritage?

\section{Under what conditions might multi-sited ethnography be applied?}

The risks inherent in multi-sited ethnography are reminiscent of the criticisms expressed by various authors concerning its rapid research methods. For Olivier de Sardan (2008), such research displays a lack of theoretical and methodological rigor and, according to Randall, Harper \& Rouncefield (2007), it is "quick and dirty ethnography" or "lightweight ethnography". This issue is compounded by the anthropologist's uncertain status in the field and the difficulty of undertaking in-depth research in several places at once. Another challenge of multisited ethnography is combining synchronic analysis of a situation with the observation of diachronic transformations-what Glaeser (2006) calls "processual ethnography". Theoretically, multi-sited ethnography is necessarily processual and lends itself to the study of circulations, networks, connections, borrowings, and rejections brought about by heritagization. Of course, the difficulties are multiplied if 
there are several researchers, for example from the same project, each working on several fieldwork sites.

Of the three "food heritage configurations" described above (see Footnote 4), we must first remember the starting objective was not to observe food heritage within a multi-sited ethnographic perspective at all costs. Instead, an open epistemological position was maintained in order to learn lessons from the specific field research at each site, but in relation to each other. In other words, the idea was not to begin with heritage as a categorical imperative or assume its existence as a point of principle. Nor was it to consider the multi-sited approach as a methodological panacea. Rather, it was to interrogate a body of evidence (practices, discourses, experiences, objects, and documents) relating to the way cuisine is understood and valued in various sites: how it is transmitted and remembered, how the use of natural and cultural resources is targeted, and how ideas, people, and objects circulate. The fieldwork site thus presents itself as a "building site for research", where one can observe an entire body of practices and performances or collect discourses to act as complementary samples. The hypothesis is that examining particular and complementary situations not only favors the accumulation of knowledge, but also reveals the logic of actions, initiatives, and activities relating to heritage and allows them to be put into perspective. Multi-sited ethnography focused on food heritage can thus reveal practices, discourses, and representations that most likely remain unnoticed within a single fieldwork site. Through multi-sited research studies, the emphasis is placed on the tensions between the universalist scope of food heritage and the diversity of local food heritages, which may resist, contest, or be instrumentalized to some degree by industry, tourism, or politics.

\section{What is the role of multi-site comparison?}

Fundamentally, how can we create synergies between several multi-sited investigations on food heritage? On what can we base these? And what do we want to show by doing so? At first glance, it seems difficult to establish comparisons between three food heritage configurations that are extremely different from one another, particularly as heritage spreads across the most socially, politically, economically, historically, and culturally diverse regions of the world. Does multisited ethnography thus risk becoming simply a bastard form of comparativism of food models or culture? As Descola (2005) writes more generally on the epis- 
temological pathway between ethnology and anthropology, "the risk is that we lose in intensity what we gain in generality".

My hypothesis is that the study of food heritage has a lot to lose through oneto-one comparison, which is by definition incomplete, and everything to gain by putting into perspective the ways in which it is used in diverse contexts. Additionally, the fact that the comparison is made after the research, and that it is not a stated goal at the outset, does not seem a fundamental flaw. It is better to compare after the research than not to compare at all. Detailed ethnographies, when put in a multi-site perspective, allow evidence to be selected based on the unique features of each fieldwork site in order to reconstruct processes and bring out analytic synergies. In relation to food heritage, this could mean studying:

i. its links to official or institutionalized forms of other types of heritage;

ii. the ways in which identity is mobilized through food heritage;

iii. the role of varying degrees of manipulation of memory, nostalgia, and emotions related to food heritage;

iv. the importance of the interplay between the local, the regional, and the international in the making of food heritage;

v. the primordial role of money, even in forms of intangible heritage.

In order to shed light on these synergies, several means of analysis can be used:

i. identifying the groups of actors mobilized in food heritage configurations;

ii. studying how actors are organized in the promotion of food heritage;

iii. analyzing the media used (e.g., newspapers, TV, posters, or the internet) for the promotion of food heritage;

iv. deciphering what could be called the "grammar of food heritagization" (the narratives used, means of semantic and visual manipulation, and the "invention of tradition").

The idea is to conduct ethnographic studies of the expressions, adaptations, reinterpretations, and transformations of food heritage and the rejections it ultimately provokes. Simply increasing the number of site studies, and juxtaposing them, does not help to reveal these synergies. By contrast, multi-sited ethnography, with the type of structured comparison it induces, encourages us to explore them, through the perspective it offers and the different levels it allows us to consider. Methodologically, it offers the "constructive misunderstanding" spoken of by Sahlins (1981). This is not about working in the same way in every fieldwork site, but about deliberately provoking contradiction, changing perspective, and gaining generality by starting from common units of analysis - in this case, food heritage. 


\section{Towards "translocalization of food heritage"?}

Without a doubt, one of the main difficulties of multi-sited ethnography is adapting to the moving and changing character of food heritage and to the virtual and real spaces where it manifests. Conducting multi-sited ethnographies of food heritage presents researchers with three key challenges: (1) embedding them in an area that may be more or less concrete and localized (e.g. the "gastronomic routes"), (2) endeavoring to follow particular objects or food ( $c f$. the idea of following the things, Marcus, 1995) as well as flesh and bone actors (such as the "female traditional cooks"), and (3) immersing in an unclear, sometimes intangible space, such as the media. This is the methodological paradox raised by Clifford (1997) regarding "translocal culture" (dwelling-in-travel) and it is reminiscent of what Csordas (2009) calls "transnationalization": how can we "inhabit" a place and at the same time "pass through" from one place to another, while considering the cultural practices, in this case the food practices, that the anthropologist aims to study? $?^{20}$

So, can we speak of the "transnationalization of food heritage"? Doing so would bring the heuristic benefit of going beyond the notion of "food globalization", which is based on the principle that various resources (human, material, and symbolic) flow from a center to supply one or several peripheries. In this center/periphery model, local re-appropriations-such as the social, cultural, symbolic, economic, and political inequalities caused by heritagization - are considerably diminished, even forgotten. By contrast, translocal and transnational perspectives place multi-centered and asymmetric power relations at the heart of analysis. These perspectives thus focus on: local, regional, and international connections, networks of circulation and exchange, phenomena by which norms are appropriated, and the creation and appropriation of scenes illustrating the constituent inequalities of food heritage. The three food heritage configurations described above show that the actors of food heritage do not necessarily originate from one single center, but instead come from various centers and peripheries. They show how the character of food heritage, and of the institutions which shape it, is multidirectional and not necessarily performative. This poses the following questions:

\footnotetext{
${ }^{20}$ An example of this paradigm at work is given by Argyriadis \& De La Torre (2012) with respect to the transnationalization of religious movements between Africa and Latin America.
} 
i. Where is food heritage produced?

ii. In what spaces is it diffused?

iii. Who are the actors associated with it?

iv. Who are its beneficiaries?

v. And, above all, who are its masters and who are the outsiders?

Of course, these general questions have no meaning unless they are resituated in the context of particular social, cultural, political, and/or economic relationships. This creates a methodological imperative to articulate an analysis of the global and the local, in order to better define the role of food heritage and the issues it raises.

\section{The "glocalization of food heritage" or the inversion of food hegemonies}

Robertson (1999) uses the notion of "glocalization" to make sense of the multiple circulations, flows, movements, and asymmetric relationships that characterize transnational demonstrations. This notion emphasizes several apparently contradictory dynamics: "internal/external", "near/far", "mobile/fixed", "forced/voluntary", and "productive/receptive". Can glocalization be applied to food heritage? Initially, it seems to take on a double task: "localizing the global" on the one hand and "transnationalizing the local" on the other. Yet, in light of the examples given, although multi-sited ethnography seems well-placed to document global dynamics on food heritage, it does not stop there. It also addresses the ways in which local actors resist, contest, appropriate, and transform food heritage. Ultimately, the multi-sited study of food heritage shows how and why individuals, groups, and institutions attempt, each in their own way, to impose the local as the sole ideological horizon of the transnational. Each food heritage configuration thus reinvents "the regional", "the national", and even "the international" by mobilizing its local natural, economic, political, cultural, and symbolic resources.

In reality, the multiplicity and interconnectedness of analytical levels-local, regional, national, transnational - come to the fore in the study of food heritage. This research subject poses the question of how natural, economic, political, and territorial resources are developed, while also raising questions of identity and cultural points of contact. Although it is clear these material and immaterial issues are based on concrete practices at the local level, this does not mean the global dimensions should be neglected. As Argyriadis and De La Torre (2012: 15) write, "the notion of glocalization allows us to understand how globalization is intrinsically linked to dynamics of relocalization". The theoretical and methodo- 
logical lesson is that the local can be used as a starting point to interrogate the global, and we can thus better appreciate the "glocal" character of food heritage.

In order to understand, analyze, and interpret food heritage as a process, from its construction to its uses, we must invert the globalizing and hegemonic perspective that underlies the implementation of food heritage in numerous parts of the world. The diachronic and synchronic dimension as well as the observation of transnational circulation, journeys, flows, and relationships, which emerge from both centers and peripheries, allows us to understand the asymmetrical power relations involved in food heritage. It also allows us to at least partially avoid supporting the forms of domination that occur when particular elements of a food culture are classified as heritage. The contextualized ethnography of the three food heritage configurations and of the practices and scenes they revealin their full aesthetic and cultural diversity-uncovers the global mercantile, ideological, political, and cultural logics that underlie them. ${ }^{21}$ Profoundly embedded as it is in glocal processes, food heritage merges with what could be called "gastrospaces", to paraphrase the notion of sociospace borrowed from Marcus (1995). These gastrospaces, which are glocal by definition, allow us to understand the specificities of food heritage and of the meaning different actors give it, provided that we are first clear on the multi-sited approach and the units of analysis discussed above.

\section{CONCLUSION}

In the 1960s and 70s, anthropology was heavily criticized as being "the daughter of Western imperialism" (Gough, 1968; Copans, 1970-1971, 1975; Leclerc, 1972; Asad, 1973) or the heir to an "era of violence" (Lévi-Strauss, 1973). ${ }^{22}$ Despite that, the authors who see pre-war anthropology as profoundly alienating, or as an implicit or explicit submission to imperialistic politics, paved the way for a series of paradigms to be ethically, theoretically, and methodologically inverted. Similar questions were asked of the monographic genre, the ethnographic relationship, reflexive criticism, and the place and role of the anthropologist in the society subject to ethnographic study (Ghasarian, 2004; Leservoisier, 2005;

\footnotetext{
${ }^{21}$ On the ambiguous relationship between money and heritagization in an Amerindian community in Brazil, see de Vienne \& Allard (2007).

${ }^{22}$ Some writers, most of whom are not anthropologists, denounced these links, sometimes well before anthropologists did so. See Tuhiwai Smith (1999) on the Maoris of New Zealand, and Deloria (1985) on Amerindians. Bourdieu \& Bensa (1985) discuss missionary ethnology in New Caledonia and Algeria.
} 
Fassin, 2008; Razy, 2018). Beyond these political criticisms, broader questions arose about the production of scientific knowledge and its links to power in all its forms. All of these issues fall within what Sperber (1982) and Vidal (2010) call the conditions of production and reproduction of "anthropological knowledge", in both academic and epistemological terms. ${ }^{23}$

Ultimately, the central question of this text is how best to make sense of the intensification of the cultural processes of globalization-appropriation, interpretation, transformation, re-signification, diversion, and rejection. I have proposed some elements of a theoretical and methodological response, based on the study of food heritage in Latin America and the application of multi-sited ethnography, a paradigmatic notion that emerged from the "decentralization of anthropology" (Cunin \& Hernandez, 2007). Examples from Bolivian and Mexican fieldwork sites provided insights on various local attempts to re-signify a cultural food practice that is profoundly embedded in the phenomena of globalization and heritagization. The challenge was to combine the analysis of a concept with an analysis of a category of action with a universal scope, food heritage, and the multiple forms of appropriation and/or rejection it provokes.

The resulting thoughts and propositions relate to the benefits and limitations of the comparative approach and of the notions of translocalization and glocalization. They indicate the emergence of a field of research and intervention, the anthropology of food heritage, which affords us new options. It can help articulate claims to identity and hopes for social, economic, political, territorial, and/or cultural integration. It can facilitate reflections on the ambiguous links between public policies and private interests. And finally, it can lead us to interrogate the contradictions between the global and the cultural economy, the development of globalized cultural tourism, and the value accorded to local resources and to a multiplicity of groups.

\section{BIBLIOGRAPHY}

Abélès M. (2008). Anthropologie de la globalisation. Paris, France: Payot.

Álvarez M., (2004). Culturas alimentarias, turismo y desarrollo. Boletín Novedades de Antropología, (48), pp. 14-18.

Appadurai, A. (1995 [1991]). Global Ethnoscapes. Notes and Queries for a Transnational Anthropology. In R. F. Fox (ed.), Recapturing Anthropology. Working in the Present (pp. 191-210). Santa Fe, NM: University of Washington Press.

${ }^{23}$ See the works of Stocking (1983) and Fabian (1983). 
Appadurai, A. (1996). Modernity at Large, Cultural Dimensions of Globalization. Minneapolis: University of Minnesota Press.

Appadurai A., (2001). Après le colonialisme. Les conséquences culturelles de la globalisation. $\mathrm{Pa}$ ris, France: Payot.

Argyriadis, K., de la Torre, R. (2012). Introducción. Del objeto al método: los desafios de la movilidad. In K. Argyriadis, S. Capone, R. de la Torre, A. Mary (eds.), Sentido contrario. Transnacionalización de religiones africanas y latinoamericanas (pp. 13-26). Mexico City, Mexico: CIESAS. https://doi.org/10.4000/books.irdeditions.17361

Arizpe, L., Amescua, C. (eds.). (2013). Anthropological Perspectives on Intangible Cultural Heritage. London, United Kingdom: Springer. https://doi.org/10.1007/978-3-319-00855-4

Arizpe Schlosser, L. (ed.). (2006). Retos culturales de México frente a la globalización. Mexico City, Mexico: Porrúa.

Asad, T. (ed.). (1973). Anthropology \& the Colonial Encounter. London, United Kingdom: Ithaca Press.

Ayora Díaz, S. I. (2012). Foodscapes, Foodfields and Identities in Yucatán. Amsterdam, Netherlands: Berghahn Books.

Ayora Diaz, S. I., Vargas Cetina, G. (eds.). (2010). Representaciones culturales: Imágenes e imaginación de lo yucateco. Mérida, Mexico: Universidad Autónoma de Yucatán.

Ayora Diaz, S. I. (in press). Translocalidad, globalización y regionalismo: Cómo entender la gastronomía regional yucateca? Anales de Antropología.

Barrera, E., Bringas, O. (2009). Rutas Alimentarias: una estrategia de negocios inclusivos que vincula las políticas agrarias y turísticas. Études Caribéennes, (13-14). https://doi.org/10.4000/etudescaribeennes.3828

Beck, U., Giddens, A., Lash, S. (eds.). (1994). Reflexive Modernization. Stanford, CA: Stanford University Press.

Bendix, R. (2012). Une salle, plusieurs sites: les négociations internationales comme terrain de recherche anthropologique. Critique internationale, 1(54), pp. 19-38. https://doi.org/10.3917/crii.054.0019

Bessière, J. (1998). Local development and heritage: traditional food and cuisine as tourist attractions in rural areas. Sociologia Ruralis, (38), pp. 21-34. https://doi.org/10.1111/14679523.00061

Bessière, J. (2013). 'Heritagization', a challenge for tourism promotion and regional development: an example of food heritage. Journal of Heritage Tourism, 8(4), pp. 275-291. https://doi.org/10.1080/1743873X.2013.770861

Bessière, J., Tibère, L. (2010). Innovation et patrimonialisation alimentaire: quels rapports à la tradition? Le Mangeur Ocha. Retrieved from http://www.lemangeurocha.com/filead$\mathrm{min} /$ images/sciences_humaines/Texte_exclusif_BESSIERE_et_TIBERE_innovation_et_patrimonialisation.pdf

Berliner, C., Bortolotto, C. (2013). Le monde selon l'Unesco. Gradhiva, (18) (special issue).

Bertacchini, E., Liuzza, C., Meskell, L., Saccone, D. (2016). The Politicization of Unesco World Heritage Decision making. Public Choice, 167(1), pp. 95-129. https://doi.org/10.1007/s11127-016-0332-9 
Bondaz, J., Graezer Bideau, F., Isnart, C., Leblon, A. (eds.). (2014). Les vocabulaires locaux du 'patrimoine'. Traductions, négociations et transformations. Zurich, Switzerland: Lit Verlag.

Bondaz, J., Isnart, C., Leblon, A. (2012). Au-delà du consensus patrimonial. Résistances et usages contestataires du patrimoine. Civilisations, 61(1), pp. 9-21. https://doi.org/10.4000/civilisations. 3113

Bortolotto, C. (2011). Le patrimoine culturel immatériel. Enjeu d'une nouvelle catégorie. Paris, France: Éditions de la Maison des Sciences de l'Homme. https://doi.org/10.4000/books.editionsmsh.3545

Bourdieu, P., Bensa, A. (1985). Quand les canaques prennent la parole. Actes de la recherche en sciences sociales, (56), pp. 69-85.

Brulotte, R., Di Giovine, M. (eds.). (2014). Edible Identities: Food as Cultural Heritage. Surrey, United Kingdom: Ashgate.

Brulotte, R., Starkman, A. (2016). Caldo de Piedra and Claiming Pre-Hispanic Cuisine as Cultural Heritage. In R. Brulotte, M. A. Di Giovine (eds.), Edible Identities: Food as Cultural Heritage (pp. 109-124). New York, NY: Routledge. https://doi.org/10.4324/9781315578781-8

Castellanos, E., Bergstresser S. (2016). The Mexican and Transnational Lives of Corn: Technological, Political, Edible Object. In R. Brulotte, M. A. Di Giovine (eds.), Edible Identities: Food as Cultural Heritage (pp. 201-218). New York, NY: Routledge. https://doi.org/10.4324/9781315578781-14

Clifford, J. (1997). Routes. Travel and Translation in the Late Twentieth Century. Cambridge, United Kingdom: Harvard University Press.

Clifford, J., Marcus, G. E. (eds.). (1986). Writing culture. The poetics and politics of ethnography. Berkeley: University of California Press.

Copans, J. (ed.). (1970-1971). Anthropologie et impérialisme. Les Temps Modernes, (293-294) (special issue).

Copans, J. (1975). Anthropologie et impérialisme. Paris, France: François Maspéro.

Csergo J. (2011). Le "repas gastronomique des Français" inscrit au Patrimoine Culturel Immatériel de l'Unesco. OCHA (observatoire CNIEL des Habitudes Alimentaires). Retrieved from $\mathrm{http} / / / \mathrm{www}$.lemangeur-ocha.com/le-repas-gastronomique-des-francais-inscrit-au-patrimoine-culturel-immateriel-de-lunesco/

Csergo, J. (2016a). La gastronomie est-elle une marchandise culturelle comme une autre? La gastronomie française à l'Unesco: histoire et enjeux. Chartres, France: Menu Fretin.

Csergo, J. (2016b). Quelques enjeux de l'inscription de patrimoines alimentaires à l'Unesco. Géoéconomie, 1(78), pp. 187-208. https://doi.org/10.3917/geoec.078.0187

Csordas, T. J. (ed.). (2009). Transnational Transcendence. Essays on Religion and Globalization. Berkeley: University of California Press.

Cunin, É., Hernández, V. A. (2007). De l'anthropologie de l'autre à la reconnaissance d'une autre anthropologie. Journal des anthropologues, (110-111), pp. 9-25.

Deloria, V. (1985). American Indian Policy in The Twentieth Century. Norman: University of Oklahoma Press.

Descola, P. (2005). Par-delà nature et culture. Paris, France: Gallimard. 
Ellison, N. (2004). Une écologie symbolique totonaque, le municipe de Huehuetla (Mexique). Journal de la Société des Américanistes, 90(2), pp. 36-52. https://doi.org/10.4000/jsa.1332

Escobar, A. (1995). Encountering Development. The Making and Unmaking of the Third World. Princeton, NJ: Princeton University Press.

Espeitx, E. (2004). Patrimonio alimentario y turismo. Pasos. Revista de turismo y patrimonio cultural, (2), pp. 193-213. https://doi.org/10.25145/j.pasos.2004.02.016

Fabian, J. (1983). Time and the Other? How Anthropology Makes its Object? Columbia, NY: Columbia University Press.

Fassin, D. (2008). Introduction. L'inquiétude ethnographique. In D. Fassin \& A. Bensa (eds.), Les politiques de l'enquête. Épreuves ethnographiques (pp. 7-15). Paris, France: La Découverte.

Geertz, C. (1973). The interpretation of cultures. Selected essays. New York, NY: Basic Books.

Ghasarian, C. (ed.). (2004). De l'ethnographie à l'anthropologie réflexive: Nouveaux terrains, nouvelles pratiques, nouveaux enjeux. Paris, France: Armand Colin.

Glaeser, A. (2006). An ontology for the Ethnographic Analysis of Social Processes: Extending the Extended Case Method. In T. M. Evens, D. Handleman (eds.), The Manchester School: Practice and Ethnographic Praxis in Anthropology (pp. 64-69). New York, NY: Berghahn Books.

Gough, K. (1968). Anthropology and imperialism. Current Anthropology, IX(5), pp. 12-27. https://doi.org/10.14452/MR-019-11-1968-04_2

Guillaud, D., Juhé-Beaulaton, D., Cormier-Salem, M.-C., Girault, Y. (eds.). (2016). Ambivalences patrimoniales au Sud. Mises en scène et jeux d'acteurs. Paris, France: Karthala.

Heinich, N. (2009). La fabrique du patrimoine. Paris, France: Éditions de la Maison des Sciences de l'Homme. https://doi.org/10.4000/books.editionsmsh.2642

Isnart, C. (2012). Les patrimonialisations ordinaires. Essai d'images ethnographiées. ethnographiques.org, (24). Retrieved from http://www.ethnographiques.org/2012/Isnart

Iturriaga, Y. (2010). Reflexiones sobre la cocina tradicional mexicana y la Unesco. Archipiélago. Revista cultural de nuestra América, 18(70): 57-59.

Juhé-Beaulaton, D., Cormier Salem, M.-C., Robert (de), P., Roussel, B. (eds.). (2013). Effervescence patrimoniale au Sud. Entre nature et société. Marseille, France: IRD. https://doi.org/10.4000/books.irdeditions.8806

Katz, E., Lazos, E. (2017). The Rediscovery of Native 'Super Foods' in Mexico. In B. Sébastia (ed.), Eating Traditional Food. Politics, identity and practices (pp. 21-47). London, United Kingdom: Routledge.

Langlois, C. (1999). Recent developments in French anthropology of France and the role of the Mission du Patrimoine Ethnologique, Cultural Anthropology, 14(3), pp. 409-416. https://doi.org/10.1525/can.1999.14.3.409

Leclerc, G. (1972). Anthropologie et colonialisme. Paris, France: Fayard.

Leservoisier, O. (ed.). (2005). Terrains ethnographiques et hiérarchies sociales. Retour réflexif sur la situation d'enquête. Paris, France: Karthala.

Lévi-Strauss, C. (1973). Anthropologie structurale, II. Paris, France: Plon. 
Marcus, G. E. (1995). Ethnography In/Of the World System: The Emergence of Multi-Sited Ethnography. Annual Review of Anthropology, (24), pp. 95-117. https://doi.org/10.1146/annurev.an.24.100195.000523

Marcus, G. E. (1998). Ethnography Through Thick and Thin. Princeton, NJ: Princeton University Press.

Marcus, G. E. (2002). Au-delà de Malinowski et après Writing Culture: à propos du futur de l'anthropologie culturelle et du malaise de l'ethnographie. Ethnographiques.org, (1). Retrieved from http://www.ethnographiques.org/2002/ᄀMarcus

Marcus, G. E., Fischer, M. M. J. (1999). Anthropology as Cultural Critique. An Experimental Moment in the Human Sciences. Chicago, IL: University of Chicago Press. https://doi.org/10.7208/chicago/9780226229539.001.0001

Matta, R. (2010). L' 'indien' à table dans les grands restaurants de Lima? Cuisiniers d'élite et naissance d'une 'cuisine fusion' à base péruvienne. Anthropology of Food, (7). https://doi.org/10.4000/aof.6592

Matta, R. (2013). Valuing Native Eating. The Modern Roots of Peruvian Food Heritage. Anthropology of Food, (S8). https://doi.org/10.4000/aof.7361

Matta, R. (2016). Food incursions into global heritage: Peruvian cuisine's slippery road to Unesco. Social Anthropology, 24(3), pp. 338-352. https://doi.org/10.1111/1469-8676.12300

Moncusí, A., Santamarina, B. (2008). Bueno para comer, bueno para patrimonializar. La propuesta de la cocina mexicana como patrimonio inmaterial de la humanidad. In M. Álvarez, X. Medina (eds.) Identidades en el plato. El patrimonio cultural alimentario entre Europa y América (pp. 127-142). Barcelona, Spain: Icaria-Observatorio de la Alimentación.

Nash, J. C. (1979). We Eat the Mines and the Mines Eat Us: Dependency and Exploitation in Bolivian Tin Mines. New York, NY: Columbia University Press.

Nielsen, B. (2013). L'Unesco et le culturellement correct. Gradhiva, (18), pp. 74-97. https://doi.org/10.4000/gradhiva.2713

Olivier de Sardan, J.-P. (1997). Anthropologie et développement. Essai en socio-anthropologie du changement social. Paris, France: APAD-Karthala.

Olivier de Sardan, J.-P. (2008). La rigueur du qualitatif. Les contraintes empiriques de l'interprétation socio-anthropologique. Louvain-La-Neuve, Belgium: Academia Bruylant.

Rabinow, P. (1977). Reflections on Fieldwork in Morocco. Berkeley: University of California Press.

Rabinow, P. (1999). American Moderns: On Sciences and Scientists. In G. E. Marcus (ed.), Critical Anthropology Now. Unexpected Contexts, Shifting Constituencies, Changing Agendas (pp. 305-333). Santa Fe, NM: School of American Research Press.

Randall, D., Harper, R., Rouncefield, M. (2007). Fieldwork for Design: Theory and Practice. London, United Kingdom : Springer. https://doi.org/10.1007/978-1-84628-768-8

Razy, É. (2018). Practising ethics: from general anthropology to the anthropology of childhood and back again. AnthropoChildren, (8). Retrieved from https://popups.uliege.be/2034-8517/index.php?id=3113

Robertson, R. (1995). Glocalization: Time-Space and Homogeneity-Heterogeneity. In M. Featherstone, S. Lash, R. Robertson (eds.), Global Modernities (pp. 25-44). London, United Kingdom: Sage. https://doi.org/10.4135/9781446250563.n2 
Sahlins, M. (1981). Historical Metaphors and Mythical Realities. Structure in the Early History of the Sandwich Islands Kingdom. Ann Arbor: University of Michigan Press. https://doi.org/10.3998/mpub.6773

Sarkis Fernández, D., Sarkis Fernández, T. (2007). Anthropologies émergentes et nouvelles pratiques discursives de 'gestion du social'. Journal des anthropologues, (110-111), pp. 227 248. https://doi.org/10.4000/jda.2455

Sperber, D. (1982). Le savoir des anthropologues. Trois essais. Paris, France: Hermann.

Stocking, G. W. (ed.). (1983). Observers Observed. Essays on Ethnographic Fieldwork. Madison: University of Wisconsin Press.

Suremain (de), Ch.-É. (2015). Introduction. Fabric-acteurs, recherche, patrimoine: une relation sous haute tension. In Ch.-É de Suremain, J.-C. Galipaud (eds.), Les fabric-acteurs de patrimoine. Implication, participation et postures des chercheurs dans la patrimonialisation (pp. 5-17). Igé-Bondy, France: L’Étrave-IRD.

Suremain (de), Ch.-É. (in press). ¿Una comida perturbante? Razón y desatino patrimonial del apthapi en Bolivia. In N. Rebaï, A.-G. Billaut, E. Katz, Ch.-É. de Suremain (eds.), Patrimonios Alimentarios en América Latina: recursos locales, actores y globalización. Quito, Ecuador: IFEA, FLACSO.

Tellström, R., Gustafsson, I. G., Mossberg, L. (2006). Consuming heritage: The use of local food culture in branding. Place branding and public diplomacy, 2(2), pp. 130-143. https://doi.org/10.1057/palgrave.pb.5990051

Timothy, D. J. (2016). Heritage cuisines. Traditions, cuisines and tourism. New York, NY: Routledge. https://doi.org/10.4324/9781315752525

Tornatore, J.-L. (2004). La difficile politisation du patrimoine ethnologique. Terrain, (42), pp. 149-160. https://doi.org/10.4000/terrain.1791

Tuhiwai Smith, L. (1999). Decolonizing Methodologies: Research and Indigenous Peoples. London, United Kingdom: Zed Books.

Vidal, L. (2010). Faire de l'anthropologie. Santé, science et développement. Paris, France: La Découverte.

Vienne (de), É., Allard, O. (2007). Pour une poignée de dollars? Transmission et patrimonialisation chez les Trumai du Brésil central. Cahiers des Amériques Latines, (48-49), pp. 126-165.

Zabludovski, G. (1996). Patrimonialismo y modernización. Revista mexicana de ciencias políticas y sociales, 41(163), pp. 251-254. https://doi.org/10.22201/fcpys.2448492xe.1996.163.49659 